\title{
Regulation of oestrogen-induced $L H$ release in male and female marmoset monkeys (Callithrix jacchus)
}

\author{
J. K. Hodges* \\ M.R.C. Centre for Reproductive Biology, 37 Chalmers Street, Edinburgh EH3 9EW, U.K.
}

\begin{abstract}
Summary. The positive-feedback action of oestradiol-17 $\beta$ on $\mathrm{LH}$ release was studied in gonadectomized male and female and intact male marmoset monkeys. Positive feedback was observed in normal intact males in response to a single subcutaneous injection of $35 \mu \mathrm{g}$ oestradiol benzoate. The sustained elevation in oestradiol-17 $\beta$ levels achieved by the injections resulted in a marked suppression of circulating testosterone concentrations. Subcutaneous injections $(0.5 \mathrm{mg} /$ injection $)$ of testosterone or dihydrotestosterone to gonadectomized males and females immediately following and $8 \mathrm{~h}$ after oestradiol benzoate failed to inhibit positive feedback. Similar treatment with progesterone $(1.0 \mathrm{mg} /$ injection) tended to standardize both positive and negative components of the feedback response. In contrast, progesterone implants (achieving progesterone concentrations similar to those obtained with the injections), maintained during and for 8 days before the oestradiol benzoate treatment, effectively inhibited positive feedback. LH responses to the various treatments were similar in gonadectomized males and females. These data suggest a relative unimportance of testicular secretions in suppressing oestrogen-induced LH release in the adult marmoset and indicate similarities between the control of positive feedback in male and female primates.
\end{abstract}

\section{Introduction}

In rodents (Barraclough, 1966; Brown-Grant \& Sherwood, 1971) and sheep (Short, 1974; Clarke, Scaramuzzi \& Short, 1976) the mechanism which regulates cyclic gonadotrophin function is rendered permanently inoperative in males by testicular hormones secreted during a critical period of development. This sexual differentiation of the cyclic control centre in males abolishes the capacity to respond to an oestrogen stimulus with a gonadotrophin surge (i.e. positive feedback) (Neill, 1972; Karsch \& Foster, 1975; Buhl, Norman \& Resko, 1978). In primates, however, it has been shown that the mechanism controlling the positive feedback response is not sexually differentiated to the same extent (Goy \& Resko, 1972; Karsch, Dierschke \& Knobil, 1973; Knobil, 1974). Castrated (but not intact) male rhesus and pig-tailed macaques chronically treated with low doses of oestrogen will release LH in response to an additional oestrogen stimulus (Karsch et al., 1973; Steiner, Clifton, Spies \& Resko, 1976; Steiner, Schiller, Barber \& Gale, 1978). Oestrogen-induced LH release has also been reported in man by some workers (Dörner, Rohde, Stahl, Krell \& Masius, 1975; Kulin \& Reiter, 1976) but not by others (Van Look, Hunter, Corker \& Baird, 1977). More recently, a positive discharge of LH in response to a single oestrogen injection was clearly described in intact as well as castrated male marmoset monkeys (Hodges \& Hearn, 1978).

* Present address: Wellcome Laboratories of Comparative Physiology, Institute of Zoology, The Zoological Society of London, Regent's Park, London NW1 4RY, U.K. 
A more detailed study in the marmoset, designed to examine the positive feedback response in males and females under different hormonal conditions, is now described. LH responses to a single injection of oestradiol benzoate were examined in normal intact males. The effects of physiological levels of testosterone and dihydrotestosterone, and different regimens of progesterone treatment, on oestrogen-induced LH release in gonadectomized male and female marmosets are also described.

\section{Materials and Methods}

Sexually mature male and female marmoset monkeys from the M.R.C. Primate Colony, Edinburgh, were used. The animals weighed $0.22-0.32 \mathrm{~kg}$ and full details of their management have been published elsewhere (Hearn, Lunn, Burden \& Pilcher, 1975).

\section{Procedure}

Six intact males were given $35 \mu$ g oestradiol benzoate (Organon Laboratories, Ltd.) as a single subcutaneous injection in $0.1 \mathrm{ml}$ arachis oil. Three groups of marmosets (gonadectomized at least 3 months before the study), each comprising 4 males and 4 females, received similar oestrogen treatment followed immediately and after $8 \mathrm{~h}$ by single subcutaneous injections of 0.5 mg testosterone (Group 1), $0.5 \mathrm{mg}$ dihydrotestosterone (Group 2) or $1.0 \mathrm{mg}$ progesterone (Group 3) in $0.1 \mathrm{ml}$ arachis oil. (Progesterone in oil was supplied by Organon Laboratories, Ltd Morden, Surrey; testosterone and dihydrotestosterone were obtained as crystalline preparations from Sigma Chemical Co. (Poole, Dorset) and dissolved in arachis oil as required.) The 4 gonadectomized males and 4 gonadectomized females in Group 4 received progesterone implants $(1 \times 50 \mathrm{mg}$ plus $1 \times 25 \mathrm{mg}$; Organon $) 8$ days before a single injection of $35 \mu \mathrm{g}$ oestradiol benzoate in arachis oil. Progesterone implants were placed subcutaneously through an incision made ventrolaterally in the abdominal area. To serve as controls, 12 intact males and 12 gonadectomized animals ( 6 males, 6 females) were given an injection of $0.1 \mathrm{ml}$ arachis oil only.

Blood samples were collected from experimental and control animals immediately before and $8,20,24,28$ and $36 \mathrm{~h}$ after the oestradiol benzoate or arachis oil injection and an additional sample was collected after $48 \mathrm{~h}$ from all intact males. Blood $(0.4 \mathrm{ml})$ was withdrawn from the femoral vein with a heparinized $1.0 \mathrm{ml}$ syringe and placed immediately on ice. The blood was centrifuged at $500 \mathrm{~g}$ for $10 \mathrm{~min}$ at $4^{\circ} \mathrm{C}$ and the plasma was stored at $-20^{\circ} \mathrm{C}$. Animals were not sedated before venepuncture.

\section{Hormone assays}

Plasma LH and oestradiol-17 $\beta$ were measured in all samples from experimental animals. Testosterone was measured in oestrogen-treated intact males and in gonadectomized animals receiving testosterone injections (Group 1). Progesterone levels were determined in animals given progesterone injections and implants (Groups 3 and 4). LH was measured in control animals.

Plasma LH levels were determined using a heterologous double-antibody radioimmunoassay previously described in detail and validated for marmoset LH (Hodges, 1978). The assay system utilizes a rat standard preparation (NIAMDD-LH-RP1) and an anti-ovine LH antiserum (610, V, Uilenbroek). The assay has a detection limit of $20 \mathrm{ng} \mathrm{LH}-\mathrm{RP} 1 / \mathrm{ml}$, and an interassay coefficient of variation of $7 \cdot 4 \%(n=15)$.

Progesterone, testosterone and oestradiol-17 $\beta$ were measured using specific radioimmunoassays fully described by Scaramuzzi, Corker, Young \& Baird (1975), Corker \& Davidson (1978) and Baird, Swanston \& Scaramuzzi (1976), respectively. Progesterone antiserum was raised in a rabbit against progesterone-11 $\alpha_{0}$ hemisuccinate-bovine $_{i c}$ serum $_{t}$ albumin (BSA) 
conjugate. The specificity has been described by Dighe \& Hunter (1974). Antibody to testosterone was raised in a goat immunized with testosterone-3-carboxymethyl oxime conjugated to BSA. Cross-reactions of other steroids tested included $5 \alpha$-dihydrotestosterone $(25 \%)$, oestradiol- $17 \beta(0.2 \%)$ and androstenedione $(0.08 \%)$. Antiserum to oestradiol-17 $\beta$ (raised against oestradiol-6-carboxymethyl oxime-BSA in a rabbit) cross-reacted with oestrone $(3.0 \%)$, oestradiol- $17 \alpha(2.8 \%)$ and other steroids $(<1 \%)$. Cross-reaction of oestradiol benzoate in the assay was $0.38 \%$.

Validation of these assays for marmoset plasma has been described in detail by Chambers \& Hearn (1979). The assay sensitivities for progesterone, testosterone and oestradiol-17 $\beta$ are 1700, 500 and $350 \mathrm{pg} / \mathrm{ml}$, respectively. Interassay coefficients of variation were $12 \%$ for progesterone, $16 \%$ for oestradiol- $17 \beta$ and $13 \%$ for testosterone.

\section{Analysis of results}

In this study, positive feedback (negative feedback) has been defined as an increase (decrease) in circulating LH to levels exceeding two standard deviations from mean control values. While lesser responses, both positive and negative, may reflect genuine feedback effects, it was felt necessary to impose such a definition in order to avoid confusion between feedback effects and episodic LH secretion. Statistical analysis of the data was performed using an unpaired Student's $t$ test and two-way analysis of variance.

\section{Results}

\section{Intact males}

LH responses to a single injection of oestradiol benzoate in 6 individual males are shown in Text-fig. 1. In the presence of increasing plasma levels of oestradiol-17 $\beta$, there was an initial suppression of circulating LH in all animals although in 5 levels remained within the defined control limits. Plasma LH concentrations then rose abruptly to exceed control limits in 4 males, maximum LH levels occurring $28 \mathrm{~h}$ after the oestrogen injection. A slight rise in LH in the remaining 2 males was insufficient to be classified as positive feedback. Despite this, mean LH concentrations were significantly different from corresponding mean control values at each sampling time after the injection of oestrogen (Table 1). The increase in plasma oestradiol-17 $\beta$ concentrations was associated with a marked suppression of circulating testosterone concentrations, mean ( \pm s.e.m.) levels falling from $27.0 \pm 3.0 \mathrm{ng} / \mathrm{ml}$ before the oestrogen injection to $7.5 \pm 1.0 \mathrm{ng} / \mathrm{ml}$ after $8 \mathrm{~h}$. The duration of testosterone suppression is not clear because of the bleeding schedule, but would appear to be less than $24 \mathrm{~h}$.

Table 1. Mean \pm s.e.m. circulating $\mathrm{LH}$ concentrations $(\mathrm{ng} / \mathrm{ml})$ in intact male marmosets at various times after injection of oestradiol benzoate or oil (controls)

\begin{tabular}{lcccccc}
\hline & & \multicolumn{5}{c}{ Time after injection (h) } \\
\cline { 3 - 7 } \multicolumn{1}{c}{ Treatment } & $\begin{array}{c}\text { No. of } \\
\text { animals }\end{array}$ & 0 & 8 & 24 & 28 & 36 \\
\hline Oil & 12 & $44 \cdot 2 \pm 4 \cdot 7$ & $45 \cdot 9 \pm 3 \cdot 1$ & $40 \cdot 3 \pm 3 \cdot 4$ & $40 \cdot 5 \pm 3 \cdot 8$ & $45 \cdot 2 \pm 3 \cdot 5$ \\
Oestradiol & 6 & $49.6 \pm 6 \cdot 2$ & $31 \cdot 2 \pm 4 \cdot 9 \dagger$ & $108 \cdot 0 \pm 21 \cdot 2^{*}$ & $132 \cdot 3 \pm 28 \cdot 4^{*}$ & $111 \cdot 0 \pm 18 \cdot 1^{*}$ \\
\hline
\end{tabular}

Values significantly different from corresponding control value; ${ }^{*} P<0.001, \uparrow P<0.01$.

\section{Gonadectomized males and females}

The LH response to injections of oestradiol benzoate and testosterone (Group 1) is shown in Text-fig. 2. Testosterone concentrations rose to about $20 \mathrm{ng} / \mathrm{ml}$ (normal range for males, 5-50 
$\mathrm{ng} / \mathrm{ml}$ ) after $8 \mathrm{~h}$ and remained at or above this level until $20 \mathrm{~h}$ after the initial injection. The increment in circulating testosterone concentrations after the second injection of testosterone at $8 \mathrm{~h}$ was not detected with the bleeding schedule used. As oestradiol-17 $\beta$ and testosterone concentrations rose, LH levels fell and negative feedback was seen in 3 animals. All males subsequently showed an increase in circulating LH to exceed control limits, with maximum levels occurring after $24 \mathrm{~h}$.
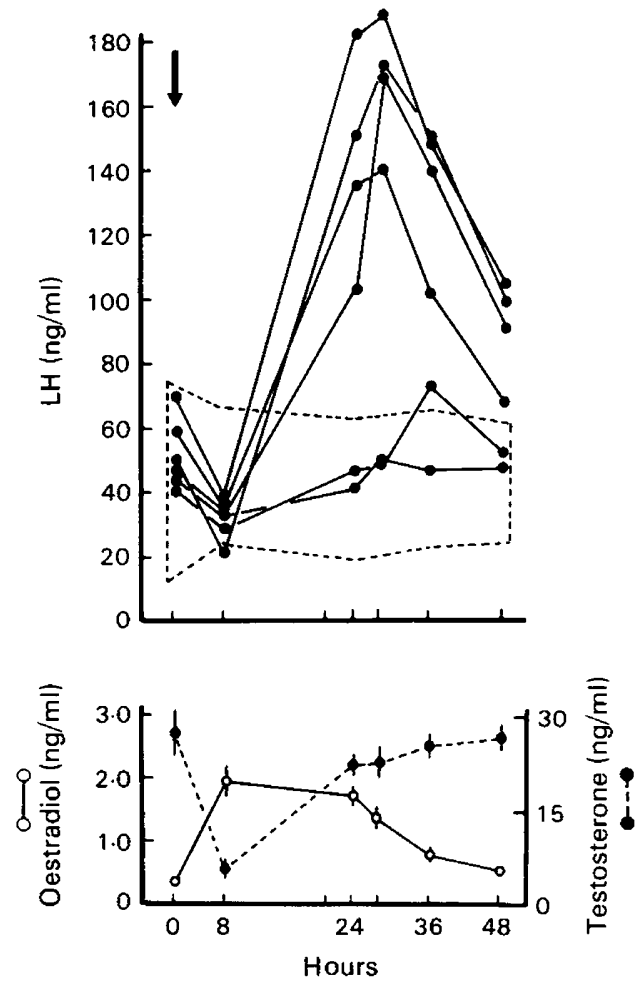

Text-fig. 1. Plasma LH (individual values), oestradiol-17 $\beta$ and testosterone (mean \pm s.e.m.) concentrations in 6 intact male marmosets after a single s.c. injection of $35 \mu \mathrm{g}$ oestradiol benzoate in oil (arrow). The broken lines represent the limits of 2 standard deviations above and below the mean control LH levels in 12 intact males (oil injection).

The effect of dihydrotestosterone on oestrogen-induced LH release (Group 2) is shown in Text-fig. 3. Mean circulating oestradiol-17 $\beta$ levels achieved by the injections were similar to those obtained previously. Dihydrotestosterone concentrations were not measured, although the dose administered and the times of injections relative to oestradiol benzoate were the same as for Group 1. Circulating LH concentrations indicate that negative and positive feedback occurred in all animals, and that maximum levels were attained after $24 \mathrm{~h}$.

The effect of progesterone by injections or implants on the LH response to oestrogen is shown in Text-fig. 4. Mean circulating progesterone concentrations achieved by the injections rose to approximately $35 \mathrm{ng} / \mathrm{ml}$ by $8 \mathrm{~h}$ and remained above this level until $20 \mathrm{~h}$ after the initial injection (normal luteal-phase range, 20-60 ng/ml). Maximum progesterone levels achieved by the sécond injection are not known, but probably exceeded $40 \mathrm{ng} / \mathrm{ml}$. LH responses were very consistent between individuals, negative followed by positive feedback being observed in all animals. The progesterone implants maintained circulating progesterone concentrations similar to those obtained with the injections and LH levels were clearly suppressed in all animals after $8 \mathrm{~h}$. However, LH values rose above control limits in only 1 animal and a large variation in LH responses occurred in the others. 

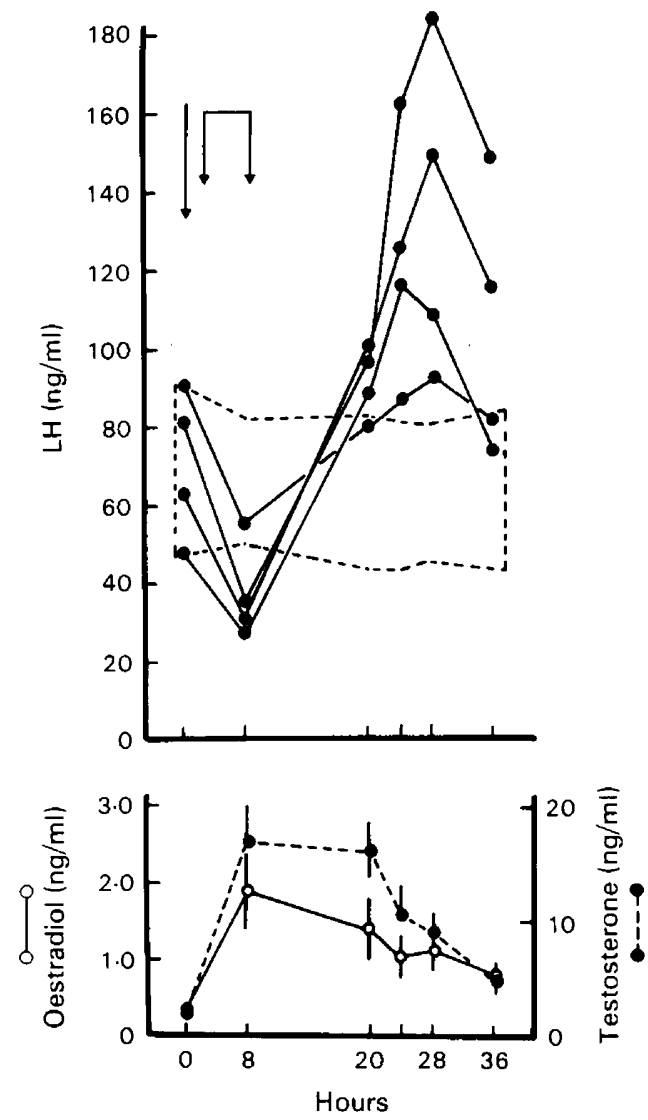

Text-fig. 2. Plasma LH (individual values), oestradiol-17 $\beta$ and testosterone (mean \pm s.e.m.) concentrations in 4 gonadectomized male marmosets after a single s.c. injection of $35 \mu \mathrm{g}$ oestradiol benzoate (arrow) and s.c. injections of $0.5 \mathrm{mg}$ testosterone (double arrow) after 0 and $8 \mathrm{~h}$. The broken lines represent the limits of 2 standard deviations above and below mean control LH levels in 6 gonadectomized males (oil injection).

Mean ( \pm s.e.m.) LH responses in gonadectomized males and females in Groups $1-4$ are shown in Table 2. In all groups, mean LH levels in males and females $8 \mathrm{~h}$ after the oestrogen injection were significantly lower than respective mean control values (not shown) $(0.001<P<$

Table 2. Summary table of the mean \pm s.e.m. circulating $\mathrm{LH}$ concentrations $(\mathrm{ng} / \mathrm{ml})$ in gonadectomized male $(\mathrm{N}=4)$ and female $(\mathrm{N}=4)$ marmosets in response to hormone treatments after treatment with oestradiol benzoate (see Text-figs 2, 3, 4a and 4b)

\begin{tabular}{|c|c|c|c|c|c|c|}
\hline \multirow[b]{2}{*}{ Treatment } & \multirow[b]{2}{*}{ Sex } & \multicolumn{5}{|c|}{ Time after oestradiol injection (h) } \\
\hline & & 0 & 8 & 24 & 28 & 36 \\
\hline Testosterone & 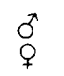 & $\begin{array}{l}67 \cdot 5 \pm 9 \cdot 5 \\
74 \cdot 0 \pm 6 \cdot 3\end{array}$ & $\begin{array}{l}37 \cdot 0 \pm 5 \cdot 8 \\
35 \cdot 7 \pm 3.8\end{array}$ & $\begin{array}{l}124.0 \pm 16.0 \\
161.0 \pm 21.9\end{array}$ & $\begin{array}{l}134.5 \pm 21.9 \\
152.0 \pm 17.2\end{array}$ & $\begin{array}{l}104.5 \pm 16.6 \\
124.8 \pm 15.2\end{array}$ \\
\hline DHT & $\begin{array}{l}0 \\
0 \\
+\end{array}$ & $\begin{array}{l}66 \cdot 0 \pm 6 \cdot 4 \\
60 \cdot 0 \pm 7 \cdot 9\end{array}$ & $\begin{array}{l}40 \cdot 2 \pm 3 \cdot 3 \\
32 \cdot 8 \pm 4 \cdot 1\end{array}$ & $\begin{array}{l}141 \cdot 0 \pm 14.0 \\
120 \cdot 8 \pm 29 \cdot 3\end{array}$ & $\begin{array}{l}123.7 \pm 11.0 \\
109.5 \pm 17.7\end{array}$ & $\begin{aligned} 104 \cdot 2 & \pm 4 \cdot 7 \\
79 \cdot 0 & \pm 16 \cdot 7\end{aligned}$ \\
\hline Progesterone, injected & $\begin{aligned} & \mathrm{d} \underbrace{\pi} \\
& \phi^{\pi}\end{aligned}$ & $\begin{array}{l}56 \cdot 7 \pm 4 \cdot 1 \\
80 \cdot 3 \pm 5 \cdot 4\end{array}$ & $\begin{array}{l}21 \cdot 0 \pm 0.4 \\
24 \cdot 0 \pm 3 \cdot 0\end{array}$ & $\begin{array}{l}119 \cdot 8 \pm 7 \cdot 7 \\
140 \cdot 5 \pm 9 \cdot 8\end{array}$ & $\begin{array}{l}121 \cdot 3 \pm 5 \cdot 1 \\
125 \cdot 5 \pm 6 \cdot 3\end{array}$ & $\begin{array}{l}100 \cdot 5 \pm 5 \cdot 6 \\
107 \cdot 3 \pm 8 \cdot 3\end{array}$ \\
\hline $\begin{array}{l}\text { Progesterone, } \\
\text { implanted }\end{array}$ & $\begin{array}{l}\delta \\
\text { O }\end{array}$ & $\begin{array}{l}51.5 \pm 6.4 \\
52 \cdot 8 \pm 6 \cdot 1\end{array}$ & $\begin{array}{c}21 \cdot 5 \pm 1 \cdot 5 \\
<20\end{array}$ & $\begin{array}{l}49 \cdot 0 \pm 9 \cdot 3 \\
45 \cdot 5 \pm 12 \cdot 1\end{array}$ & $\begin{array}{l}53.7 \pm 17.4 \\
54.0 \pm 12.1\end{array}$ & $\begin{array}{l}52 \cdot 5 \pm 7.2 \\
49.3 \pm 7.5\end{array}$ \\
\hline
\end{tabular}


0.01 , Student's $t$ test). In Groups 1,2 and 3, but not in Group 4, mean LH concentrations in males and females were higher than mean control values after 24 and $28 \mathrm{~h}(0.001<P<0.01$, Student's $t$ test). Two-way analysis of variance showed that there was no significant difference between the pattern of response in males and females for any of the treatment groups.
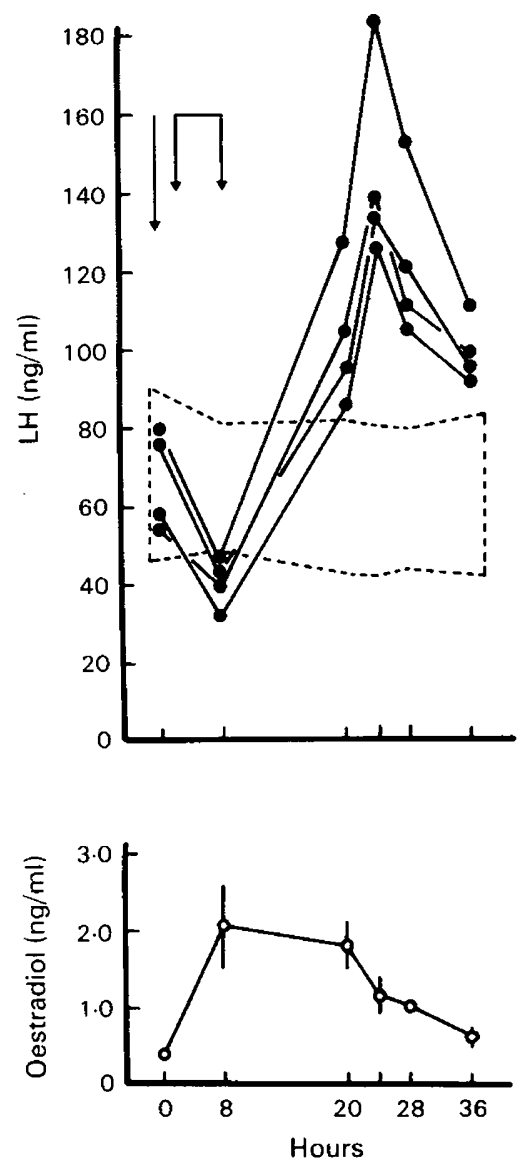

Text-fig. 3. Plasma LH (individual values) and oestradiol-17 $\beta$ (mean \pm s.e.m.) concentrations in 4 gonadectomized male marmosets after a single s.c. injection of $35 \mu \mathrm{g}$ oestradiol benzoate (arrow) and s.c. injections of $0.5 \mathrm{mg}$ dihydrotestosterone (double arrow) after 0 and $8 \mathrm{~h}$. The broken lines represent the limits of 2 standard deviations above and below mean control LH levels in 6 gonadectomized males (oil injection).

\section{Discussion}

The results of this study confirm the previous report (Hodges \& Hearn, 1978) of a positive-feedback response to oestrogen in intact as well as gonadectomized male marmoset monkeys. Although oestrogen-induced LH release has also been described in gonadectomized male rhesus monkeys (Karsch et al., 1973) and pig-tailed macaques (Steiner et al., 1978), no such response could be demonstrated in intact males of these species. Van Look et al. (1977) were unable to induce positive feedback in normal men or in subjects with testicular feminization, but a female type of $\mathrm{LH}$ release in response to oestrogen treatment was demonstrated in one patient with XY pure gonadal dysgenesis. When positive feedback has been 
reported in normal (Kulin \& Reiter, 1976) and homosexual men (Dörner et al., 1975), the data are inconclusive and the $\mathrm{LH}$ rises described were not comparable either in magnitude or duration to those seen in normal women. The existence of a clear positive-feedback response to oestrogen in an intact male primate at present therefore appears unique to the marmoset.
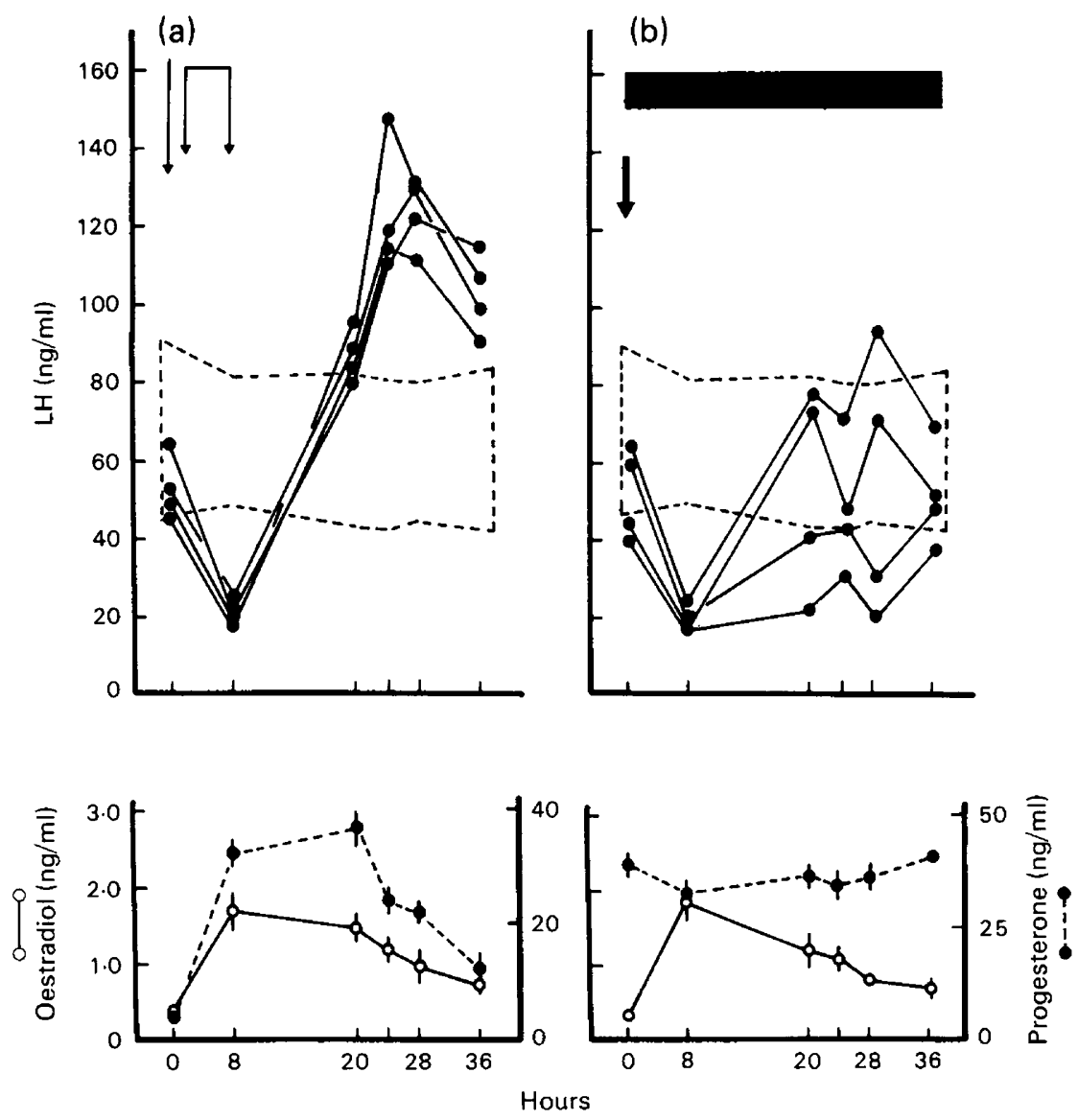

Text-fig. 4. Plasma LH (individual values), oestradiol-17 $\beta$ and progesterone (mean \pm s.e.m.) concentrations in 4 gonadectomized male marmosets after (a) a single s.c. injection of $35 \mu \mathrm{g}$ oestradiol benzoate (arrow) and s.c. injections of $1.0 \mathrm{mg}$ progesterone (double arrow) after 0 and $8 \mathrm{~h}$, and (b) implants of progesterone (horizontal bar) inserted 8 days before the oestrogen treatment. The broken lines represent the limits of 2 standard deviations above and below mean control LH levels in 6 gonadectomized males (oil injection).

Maximum oestradiol-17 $\beta$ concentrations achieved by the oestrogen injections were similar to those $(0 \cdot 8-2.0 \mathrm{ng} / \mathrm{ml})$ found in intact females immediately before the spontaneous $\mathrm{LH}$ surge (Hearn \& Lunn, 1975). Although oestradiol-17 $\beta$ concentrations fell progressively after approximately $8 \mathrm{~h}$, it is unlikely that the observed positive discharges of $\mathrm{LH}$ were due to a 'rebound' from negative feedback, because in general oestradiol-17 $\beta$ concentrations remained $>1 \mathrm{ng} / \mathrm{ml}$ until after maximum $\mathrm{LH}$ concentrations were attained, and suppression of LH levels (below basal control values) recurred $36 \mathrm{~h}$ after the LH discharge (Hodges, 1977).

Since oestrogen will induce LH release in orchidectomized (Karsch et al., 1973) but not in intact macaque monkeys (Yamaji et al., 1971; Steiner et al., 1978), it has been suggested (Knobil, 1974) that testosterone may be responsible for abolishing the positive-feedback response in intact male primates. The present data suggest that this does not pertain to the 
marmoset monkey. Although testosterone concentrations in intact males were suppressed by the oestrogen treatment before the LH surge, administration of exogenous testosterone to maintain circulating levels in the normal range for intact males throughout the experiment failed to effect a blockade of the LH discharge in gonadectomized males or females. However, testosterone can be aromatized to oestradiol-17 $\beta$ in the peripheral circulation (Longcope, Kato \& Horton, 1969) or by neural tissue (Naftolin et al., 1975), and other testicular androgens may be more effective in inhibiting oestrogen-induced $\mathrm{LH}$ release. For this reason, dihydrotestosterone, a potent reduced A-ring metabolite of testosterone which is not convertible to oestradiol-17 $\beta$ or other known oestrogens (Ito \& Horton, 1971), was also tested for its ability to abolish positive feedback. However, under the experimental conditions used in this study, no inhibition was achieved. Since circulating levels of dihydrotestosterone were not measured, the possibility that higher doses or more prolonged treatment could effect a blockade cannot be discounted.

It would be tempting to suggest that the difference between the marmoset and macaque species with respect to positive feedback in the intact male is due to a differential sensitivity to the inhibitory effects of testicular androgens. However, Steiner et al. (1978) were also unable to block oestrogen-induced LH release with various regimens of testosterone or dihydrotestosterone treatment in orchidectomized rhesus and pig-tailed macaque monkeys. These authors interpreted their data as challenging the hypothesis that testosterone or its direct metabolites mediate the observed testicular blockade in macaque species and suggested that other substances, such as inhibin, may be involved. Whatever the exact nature of the testicular substance(s) responsible for abolishing oestrogen-induced LH release in intact male macaques, it does not appear to block the response in the marmoset. Although the reason for this is not obvious, there are marked species differences in embryonic development, possibly resulting in differing organizational effects on neural components involved in the expression of positive feedback, which may in turn affect hypothalamic and/or pituitary responsiveness to steroid action in adult life. The distinctive embryology of the marmoset (e.g. high incidence of fraternal twinning and the presence of placental vascular anastomoses between twin fetuses) (Benirschke finding in women (March, Goebelsmann, Nakamura \& Mishell, 1979) and is consistent with the of oestrogens during gestation in the marmoset (Chambers \& Hearn, 1979) compared with macaque species (Challis, Davies, Benirschke, Hendrickx \& Ryan, 1974) are both factors which may be important in this regard.

The role of progesterone in the expression of the spontaneous preovulatory LH surge in primates is not fully understood. Administration of progesterone has been shown to inhibit oestrogen-induced LH release in women (Netter, Gorius, Thomas, Cohen \& Joubinaux, 1973) and intact female rhesus monkeys (Dierschke et al., 1973; Clifton, Steiner, Resko \& Spies, 1975 ) and this inhibitory effect of progesterone on oestrogen-induced LH release may account for the failure to demonstrate oestrogen-induced positive feedback during the luteal phase of the rhesus menstrual cycle (Dierschke et al., 1973). Since, however, simultaneous administration of progesterone and oestrogen to ovariectomized rhesus monkeys tended to advance rather than inhibit the onset of LH release, it has been suggested that the ovary is necessary, either directly or indirectly, for the blocking effect of progesterone (Clifton et al., 1975). The present results are inconsistent with this, but suggest instead that the length of exposure of the hypothalamicpituitary system to progesterone may be of importance in determining its influence (inhibitory or stimulatory) on oestrogen-induced positive feedback. This interpretation is supported by a recent finding in women (March, Goebelsmann, Nakamura \& Mishell, 1979) and is consistent with the idea that luteal-phase progesterone blocks positive feedback (Dierschke et al., 1973) whereas periovulatory progesterone may actually facilitate this response (Johansson \& Wide, 1969; Leyendecker, Wardlaw \& Nocke, 1972). A dual action of progesterone on oestrogen-induced LH release in gonadectomized males, although devoid of physiological significance, is an interesting observation which further exemplifies the unusual status of the male marmoset with respect to positive feedback. 
The results of the present study indicate superficial similarities between the characteristics of oestrogen-induced $\mathrm{LH}$ release in male and female marmoset monkeys. The effect of testicular secretions on the positive feedback mechanism in primates is not yet understood, although a positive response to oestrogen can still be obtained in the male marmoset despite the presence of active testes. The persistence of a positive feedback response in the male is unlikely to have any physiological significance in the control of $\mathrm{LH}$ secretion, but does lend support to the idea that the ability to release $\mathrm{LH}$ in response to oestrogen may be an intrinsic characteristic of the primate hypothalamic-pituitary unit, regardless of sex. Why positive feedback in normal intact males can be demonstrated in the marmoset, but apparently not in man or macaques is an interesting question which remains to be answered.

I thank Dr J. P. Hearn for his advice during this study, and for performing ovariectomies; Dr J. Th. J. Uilenbroek for the LH antiserum; Mr F. J. Burden for care and maintenance of the animals; and Professor R. V. Short, F.R.S., for his criticism and advice.

\section{References}

Baird, D.T., Swanston, I. \& Scaramuzzi, R.J. (1976) Pulsatile release of $\mathrm{LH}$ and secretion of ovarian steroids in sheep during the luteal phase of the estrous cycle. Endocrinology 98, 1490-1496.

Barraclough, C.A. (1966) Modifications in the CNS regulation of reproduction after exposure of prepubertal rats to steroid hormones. Rec. Prog. Horm. Res. 22, 503-539.

Benirschke, K. \& Brownhill, L.E. (1962) Further observations on marrow chimaerism in marmosets. Cytogenetics 1, 245-257.

Brown-Grant, K. \& Sherwood, M.R. (1971) The 'early androgen syndrome' in the guinea pig. J. Endocr. 49, 277-291.

Buhl, A.E., Norman, R.L. \& Resko, J.A. (1978) Sex differences in estrogen-induced gonadotropin release in hamsters. Biol. Reprod. 18, 592-597.

Challis, J.R.G., Davies, I.J., Benirschke, K., Hendrickx, A.G. \& Ryan, K.J. (1974) The concentrations of progesterone, estrone, estradiol-17 $\beta$ in the peripheral plasma of the rhesus monkey during the final third of gestation and after the induction of abortion with $\mathrm{PGF}_{2}$. Endocrinology 95, 547-553.

Chambers, P.L. \& Hearn, J.P. (1979) Peripheral plasma levels of progesterone, oestradiol-17 $\beta$, oestrone, testosterone, androstenedione and chorionic gonadotrophin during pregnancy in the marmoset monkey, Callithrix jacchus. J. Reprod. Fert. 56, 23-32.

Clarke, I.J., Scaramuzzi, R.J. \& Short, R.V. (1976) Sexual differentiation of the brain: endocrine and behavioural responses of androgenised ewes to oestrogen. J. Endocr. 71, 175-176.

Clifton, D.K., Steiner, R.A., Resko, J.A. \& Spies, H.G. (1975) Estrogen-induced gonadotropin release in ovariectomized rhesus monkeys and its advancement by progesterone. Biol. Reprod. 13, 190-195.

Corker, C.S. \& Davidson, D.W. (1978) A radioimmunoassay for testosterone in various biological fluids without chromatography. J. Steroid Biochem. 9, 373-374.

Dierschke, D.J., Yamaji, Y., Karsch, F.J., Weick, R.F., Weiss, G. \& Knobil, E. (1973) Blockage by progesterone of estrogen-induced $\mathrm{LH}$ and $\mathrm{FSH}$ release in the rhesus monkey. Endocrinology 92, 1496-1501.

Dighe, K.K. \& Hunter, W.M. (1974) A solid phase radioimmunoassay for plasma progesterone. Biochem. J. 143, 219-231.

Dörner, G., Rohde, W., Stahl, F., Krell, L. \& Masius, W.G. (1975) A neuroendocrine predisposition for homosexuality in men. Archiv. Sex Behav. 4, 1-8.

Gengozian, N. (1971) Male and female cell populations in the chimaeric marmoset. In Medical Primatology, pp. 926-938 Eds E. I. Goldsmith \& J. MoorJankowski. Karger, Basel.

Goy, R.W. \& Resko, J.A. (1972) Gonadal hormones and behaviour of normal and pseudohermaphroditic non-human female primates. Rec. Prog. Horm. Res. 18, 707-733.

Hearn, J.P. \& Lunn, S.F. (1975) The reproductive biology of the common marmoset, Callithrix jacchus. In Breeding Simians for Developmental Biology, pp. 19I-202. Eds F. T. Perkins \& P. N. O'Donoghue. Laboratory Animals Ltd, London.

Hearn, J.P., Lunn, S.F., Burden, F.J. \& Pilcher, M.M. (1975) Management of marmosets for biomedical research. Lab. Anim. 9, 125-134.

Hodges, J.K. (1977) The control of luteinising hormone secretion in the marmoset monkey, Callithrix jacchus. Ph.D. thesis, University of Edinburgh.

Hodges, J.K. (1978) Effects of gonadectomy and oestradiol treatment on plasma luteinizing hormone concentrations in the marmoset monkey, Callithrix jacchus. J. Endocr. 76, 271-281.

Hodges, J.K. \& Hearn, J.P. (1978) A positive feedback effect of oestradiol on LH release in the male marmoset monkey, Callithrix jacchus. J. Reprod. Fert. 52, 83-86.

Ito, T. \& Horton, R.J. (1971) The source of plasma dihydrotestosterone in man. $J$. clin. Invest. 50, 1621-1627.

Johansson, E.D.B. \& Wide, L. (1969) Periovulatory levels of plasma progesterone and luteinizing hormone in women. Acta endocr., Copenh. 62, 82-88. 
Karsch, E.J. \& Foster, D.L. (1975) Sexual differentiation of the mechanism controlling the pre-ovulatory discharge of luteinizing hormone in the sheep. Endocrinology 97, 373-379.

Karsch, F.J., Dierschke, D.J. \& Knobil, E. (1973) Sexual differentiation of pituitary function: apparent difference between primates and rodents. Science, N.Y. $179,484-486$.

Knobil, E. (1974) On the control of gonadotropin secretion in the rhesus monkey. Rec. Prog. Horm. Res. 30, 1-46.

Kulin, H.E. \& Reiter, E.O. (1976) Gonadotrophin and testosterone measurements after oestrogen administration to adult men, prepubertal and pubertal boys, and men with hypogonadotrophism: evidence for maturation of positive feedback in the male. Pediat. Res. 10, 46-51.

Leyendecker, G., Wardlaw, S. \& Nocke, W. (1972) Experimental studies on the endocrine regulations during the periovulatory phase of the human menstrual cycle. The effects of exogenous $17 \beta$ oestradiol and progesterone on the release of pituitary luteinizing and follicle stimulating hormones. Acta endocr., Copenh. 71, 160-178.

Longcope, C., Kato, T. \& Horton, R. (1969) Conversion of blood androgens to estrogens in normal adult men and women. J. clin. Invest. 48, 2191-2201.

March, C.M., Goebelsmann, U., Nakamura, R.M. \& Mishell, D.R. (1979) Roles of estradiol and progesterone in eliciting the midcycle luteinizing hormone and follicle stimulating hormone surges. J. clin. Endocr. Metab. 49, 507-513.

Naftolin, F., Ryan, K.J., Davies, I.J., Reddy, C.C., Flores, F., Petro, Z., Kuhn, M., White, R.J., Takaoka, Y. \& Wolin, L. (1975) The formation of estrogens by central neuroendocine tissues. Rec. Prog. Horm. Res. 31, 295-319.

Neill, J.D. (1972) Sexual differences in the hypothalamic regulation of prolactin secretion. Endocrinology 90 , 1154-1159.

Netter, A., Gorius, A., Thomas, K., Cohen, M. \& Joubinaux, J. (1973) Blocage du pic d'ovulation de LH et FSH par la progestérone à faibles doses chez la femme. Annls Endocr. 34, 430-435.

Scaramuzzi, R.J., Corker, C.S., Young, G. \& Baird, D.T. (1975) Production of antisera to steroid hormones in sheep. In Steroid Immunoassay, pp. 111-122. Eds E. H. D. Cameron, S. G. Hillier \& K. Griffiths. Alpha Omega Alpha, Cardiff.

Short, R.V. (1974) Sexual differentiation of the brain of the sheep. In Sexual Endocrinology of the Perinatal Period, pp. 121-142. Eds M. G. Forest \& J. Bertrand.

Steiner, R.A., Clifton, D.K., Spies, H.G. \& Resko, J.A. (1976) Sexual differentiation and feedback control of luteinizing hormone secretion in the rhesus monkey. Biol. Reprod. 15, 206-212.

Steiner, R.A., Schiller, H.S., Barber, J. \& Gale, C.C. (1978) Luteinizing hormone regulation in the monkey (Macaca nemestrina): failure of testosterone and dihydrotestosterone to block the estrogen-induced gonadotropin surge. Biol. Reprod. 19, 51-56.

Van Look, P.F.A., Hunter, W.M., Corker, C.S. \& Baird, D.T. (1977) Failure of positive feedback in normal men and subjects with testicular feminization. Clin. Endocr. 7, 353-366.

Yamaji, T., Dierschke, D.J., Hotchkiss, J., Bhattacharya, A.N., Surve, A.H. \& Knobil, E. (1971) Estrogen induction of $\mathrm{LH}$ release in the rhesus monkey. Endocrinology 89, 1034-1041.

Received 27 February 1980 